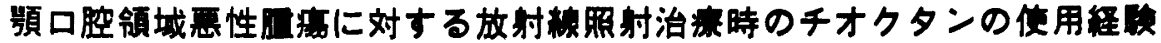

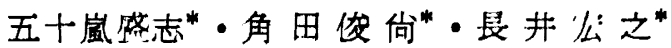

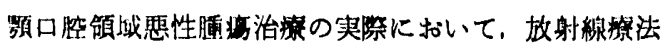
は欠くことのできない治球法である。その儖休沁用に際 しては，許し5万筑囲の大線上照射が必要とされている

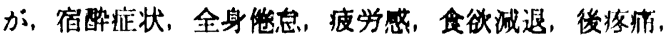

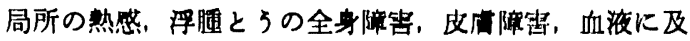
ほす寸影整とうの副作用が程度の差はあるが発現し，时に は照射を中止しなければならない垥合む起るむのであ

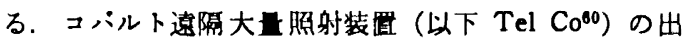
現以来，これら副作用がX線梁部治撩に比して少なくな り，とくに額口腔領域における放射線療法は，身体他部 に比して大綜五炤射が可能となり治療成績の向上をみる に至つたことは幾多先人の報告するところである．しか

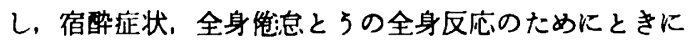
は充分な線量を照射しえないで一時中止のやむなき症例 に遭遭することもある. 全身反応の発生原因に関して は，ヒスタミン形成説, 自律神释失調説, ラジオトキシ ン中毒説，肝障害説などがあけ湆られているが，現在なお 発生機序は不明である。 またその発現率および剭度は， 照射部位によつて異なり，個人差む顕著であることが知 られている，当科においては，颗口腔領域悪性腫痬治療 の臨床に, 従来からいろいろな肝仳護剤を併用してきて いる. 近時はチオクタン（以下 TA）の使用を試みてい るが，TA は，従来から使用されている宿酔防止のため

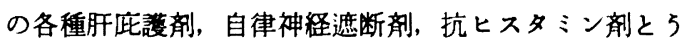
と全く性質を異にするにすかかわらず放射線療法時の副 作用とくに宿酔防止になんらかの役割をはたすごとく考 えられたので，その臨床経験について述へる。

I チオクタンの性状

1. 化学構造

$$
\stackrel{\mathrm{I}}{\mathrm{S}} \stackrel{\mathrm{S}}{\mathrm{CH}_{2}} \stackrel{\mathrm{C}}{\mathrm{C}} \mathrm{H}-\mathrm{CH}_{2}-\mathrm{CH}_{2}-\mathrm{CH}_{2}-\mathrm{CH}_{2}-\mathrm{COOH}
$$

2. TA の体内代謝（和田, 小坂, 三辺, 林, 桝屋ら） 焦性ブドウ酸， $\alpha$ ケトグルタール酸とうの酸化に対す る補酵素（酸化分解反応の触媒）

3. 解毒（上田，人見，高橋ら）

SH 基を有するので重金属との結合が考えられ，また 全般の生体内酸化作用を促進すると思われるので，体内 の有毒物質の分解をうながす.

4. 抗壊死作用（桝屋, 脇坂, 山田ら）

* 東京都新宿区戸山町一

国立東京第一病院㐘科口腔外科

（指導顧問佐藤伊吉教授）

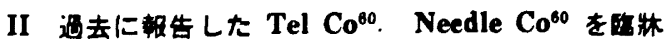
応用时の䣦作用（我 I 照)

多くの症例において，照射開始後 2 日〜 5 日位から， いわゆる宿酷拉状の発現をみている，宿睟のために照射 を一時中此した症例を 4 例みとめた。

攻I照射の全身反庆（TA 末使用）

\begin{tabular}{|c|c|c|c|c|}
\hline 反应 & $\begin{array}{l}\text { 大至遇陑 } \\
50 \mathrm{c} \\
\sim 100 \mathrm{c}\end{array}$ & $\begin{array}{c}\left(\begin{array}{c}1 \text { 日 } 200 \gamma \\
8 \times 8 \mathrm{~cm}\end{array}\right) \\
500 \mathrm{c} \\
\sim 800 \mathrm{c} \\
\sim 8\end{array}$ & \multicolumn{2}{|c|}{$\begin{array}{l}\text { 局所 照 射 } \\
\text { Coso 及び「Ra」 } \\
\text { Needl }\end{array}$} \\
\hline 宿酔症状 & $3 / 31$ & $8 / 29$ & $8 / 14$ & $8 / 16$ \\
\hline 疲 当感 & $2 / 31$ & $7 / 29$ & $13 / 14$ & $11 / 16$ \\
\hline 食铁域退 & $0 / 31$ & $10 / 29$ & $13 / 14$ & $12 / 16$ \\
\hline 後疗痛 & $2 / 31$ & $0 / 29$ & $10 / 14$ & $15 / 16$ \\
\hline 局所熱感 & $1 / 31$ & $8 / 29$ & $3 / 14$ & $5 / 16$ \\
\hline 浮腫 & $1 / 31$ & $3 / 29$ & $0 / 14$ & $4 / 16$ \\
\hline
\end{tabular}

肝障害 チモール混鉛海筆すべき变化なし

1. $\mathrm{Co}^{60}$ 照射治噔では大量照射と局所照射との間に大 きな差がある。

2. Tel $\mathrm{Co}^{60}(50 \mathrm{c} \sim 100 \mathrm{c})$ 照射開始後 2 日 3 日間 宿醉症状，疲労感を訴えた患者少数あり。建繶 $7000 \gamma$ 照射可能.

3. Tel $\mathrm{Co}^{60}(500 \mathrm{c} \sim 1000 \mathrm{c})$ 照射開始 2 日 $\sim 5$ 日目

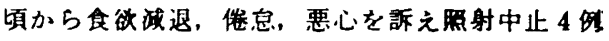
をみとめた。

4. 局所照射 (除外面照射) 開始後 2 日〜 3 日から疲 学感，痤痡を訴え，これに随伴する諸症状を訴え た.

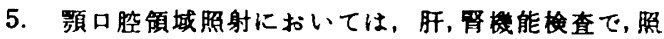
射の為に悪影をを面つたと思われる症例は皆等.

III 初回クールは TA 末使用で, 再発照射時に TA 使用例（表 II 参照）

第 3 例は, $1000 r$ ( 5 回目) 頃から中等度の宿醉が発 現し，TAを使用し 5 日目頃から回復した。他の 4 例 。 初回照射クール時にはいすれれ宿酔をみとめたが，TA を使用（照射 3 日前から）しての照射クール時には特筆 すべき反応を訴えなかつた。

IV 初回から TA 使用例（表而参照）

第 2 例，第 5 例に軽度の宿酔をみとめたが，照射続行 に支障をみなかつた。

$$
\text { 考案 }
$$

放射線照射による全身反応としての宿酔の発生機序は: 複雑で，今なお定説がない，症状も患者の訴えに頼る以。 
表 II 照射の全身反応, TA 使用（初発枺使用, 再発時使用)

\begin{tabular}{|c|c|c|c|c|c|c|c|c|c|c|c|}
\hline 氏 & 名 & 病 & 名 & 今程照射目的 & $\begin{array}{l}\text { 前回照射量 } \\
\text { TA 未使用 }\end{array}$ & 応 & $\begin{array}{l}\text { 白血球数 } \\
\text { 前 後 }\end{array}$ & \multicolumn{2}{|c|}{$\begin{array}{l}\text { 今回照射量 } \\
\mathrm{TA} \text { 使 用 }\end{array}$} & 応 & $\begin{array}{l}\text { 白血球数 } \\
\text { 前 後 }\end{array}$ \\
\hline$\hat{\sigma}$ & 51 才 & 再 III & 癌 & 内転浸 III 度 & \multicolumn{2}{|c|}{$\begin{array}{c}\mathrm{T} 6000 \gamma \rightarrow 3 \text { 日目より宿酔疲 } \\
\text { 学 } \\
\mathrm{N} 1902 \mathrm{mch} \rightarrow \text { 終了後食欲強 } \\
\text { 度滅少 } \\
\text { T } 3000 \gamma \rightarrow 5 \text { 回目に宿酔強度 } \\
\operatorname{Ras} 10 \text { 本 } 4 \text { 日間照射中止 }\end{array}$} & $\begin{array}{l}7000 \\
\sim 3900\end{array}$ & \multicolumn{3}{|c|}{$\begin{array}{l}\operatorname{Ras} 10 \text { 本 後疼痛 } \\
T 3000 \gamma \rightarrow \text { 宿酔食欲減な } \\
\text { L }\end{array}$} & $\begin{array}{l}4200 \\
\sim 4300\end{array}$ \\
\hline 우 & 60 才 & $\begin{array}{l}\text { 煩 部 } \\
\text { 再 II }\end{array}$ & $\begin{array}{l}\text { 癌 } \\
\text { 度 }\end{array}$ & $\begin{array}{l}\text { 表·腫. II 度: } \\
\text { ラジカ ル }\end{array}$ & \multicolumn{2}{|c|}{$\begin{array}{l}\text { Ras } 15 \text { 本 } \rightarrow \text { 後疼痛 } \\
\text { T } 6000 \gamma \rightarrow 5 \text { 回目より宿酔 } \\
\text { 中度, 照射続行 }\end{array}$} & $\begin{array}{l}6800 \\
\sim 3200\end{array}$ & \multicolumn{3}{|c|}{$\begin{array}{c}\mathrm{T} 9000 \gamma \rightarrow 4 \text { 回目頃より } \\
\text { 矓暉起る }\end{array}$} & \\
\hline$\hat{j}$ & 59才 & $\begin{array}{l}\text { 上 顎 } \\
\text { 再 II }\end{array}$ & $\begin{array}{l}\text { 癌 } \\
\text { 度 }\end{array}$ & $\begin{array}{l}\text { 内.転(リン } \\
\text { パ内) } \\
\text { パリアチブ }\end{array}$ & \multicolumn{3}{|c|}{ 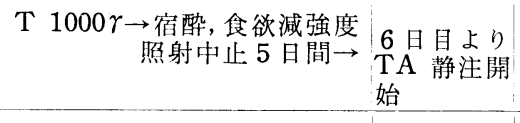 } & \multicolumn{3}{|c|}{$\begin{aligned} \mathrm{T} 7400 \gamma \rightarrow & \mathrm{TA} \text { 静注開始 } \\
& 5 \text { 日目頃より } \\
\text { 宿酔恢復 } & \end{aligned}$} & $\begin{array}{l}6500 \\
\quad \sim 5200\end{array}$ \\
\hline & 75才 & 舌 & $\begin{array}{l}\text { 癌 } \\
\text { 度 }\end{array}$ & $\begin{array}{l}\text { 腫, 中間型 } \\
\text { パリアチブ }\end{array}$ & \multicolumn{2}{|c|}{$\begin{array}{cl}\mathrm{Ra} 1680 \mathrm{mch} & \text { 疲労感軽度 } \\
& \text { 局所反応 }\end{array}$} & $\begin{array}{l}7200 \\
\sim 7000\end{array}$ & \multicolumn{3}{|c|}{$\mathrm{Ra} 2100 \mathrm{mch}$} & $\begin{array}{l}5600 \\
\quad \sim 5700\end{array}$ \\
\hline$\hat{o}$ & 63才 & 再 II & $\begin{array}{l}\text { 癌 } \\
\text { 度 }\end{array}$ & $\begin{array}{l}\text { 腫, 中問型 } \\
\text { パリアチブ }\end{array}$ & \multicolumn{2}{|c|}{$\left.\begin{array}{l}\mathrm{T} 6000 \gamma \\
\operatorname{Ra} 2100 \mathrm{mch}\end{array}\right\} \rightarrow \begin{array}{l}10 \text { 日垻より宿 } \\
\text { Ras } 10 \mathrm{mg} \\
\text { 引軽度 } 2000 \gamma \\
\text { T照射食欲減強度 }\end{array}$} & $\stackrel{7000}{\sim 5400}$ & \multicolumn{3}{|c|}{$\left.\begin{array}{l}\mathrm{T} 3000 \gamma \\
\mathrm{Ra} 10 \text { 本 }\end{array}\right\}$ 局所反応 } & $\begin{array}{l}6400 \\
\sim 6500\end{array}$ \\
\hline & 考 & \multicolumn{9}{|c|}{$\begin{array}{c}\mathrm{TA}=\text { チオクタン } 1 \text { 日 } 2 \mathrm{~A}(10 \mathrm{cc}) \text { 静注. 照射 } \mathrm{T}=\mathrm{Tel} \mathrm{Co}^{60} 1 \text { 日 } 200 \gamma \text {, 照射野 } 8 \mathrm{~cm} \times 6 \mathrm{~cm} . \\
\text { ウム． Ras=ラドンシード. 程度の内 =内向型. 表=表在型. 腫=腫瘤型. 転=転移 } \\
\text { 表亚 照射の全身反応, TA 使用 (照射開始 } 3 \text { 日前より) }\end{array}$} & $\mathrm{Ra}=$ ラジ \\
\hline 氏 & 名 & 病 & 名 & 度 & 目 的 & 照 射 量 & と反応 & & $\begin{array}{l}\text { 白血球数 } \\
\text { 前 後 }\end{array}$ & 備 & 考 \\
\hline ! & 57才 & $\begin{array}{l}\text { 下 顎 } \\
\text { II }\end{array}$ & 癌 & 内. 転. 浸 II 度 & $\begin{array}{l}\text { 前 照 射 } \\
\text { 後 照 射 }\end{array}$ & $\begin{array}{l}\mathrm{T} 3000 \gamma \rightarrow \text { D } \\
\mathrm{T} 6000 \gamma \rightarrow \text { 萑 }\end{array}$ & 反応なし & & $\begin{array}{l}5900 \\
\sim 6400 \\
\sim 3600\end{array}$ & 照射後 7 & $\begin{array}{l}\text { 目に手術 } \\
\text { より照射 }\end{array}$ \\
\hline q & $51 才$ & $\begin{array}{l}\text { 舌 } \\
\text { 再 III }\end{array}$ & $\begin{array}{l}\text { 癌 } \\
\text { 度 }\end{array}$ & 腫.転.中間型 & パリアチブ & $\mathrm{T} 12000 \gamma \rightarrow 1$ & $\begin{array}{l}15 \text { 回目垻より } \\
\text { 妿軽度, } 2 \text { ク } \\
\text { ル連続照射可 }\end{array}$ & $\begin{array}{l}\text { 宿 } \\
\text { 可能 }\end{array}$ & $\begin{array}{l}4000 \\
\sim 3100\end{array}$ & $\begin{array}{l}\text { 照射中 } 10 \\
\text { 上り食欲 } \\
\text { 独歩困難 } \\
\text { 終了 } 2 \text { 週㧓 }\end{array}$ & $\begin{array}{l}000 \gamma \text { 頃 } \\
\text { 振 } \\
\text { 恢復 }\end{array}$ \\
\hline 3 & $47 才$ & 上 & $\begin{array}{l}\text { 癌 } \\
\text { 度 }\end{array}$ & 内。 浸 II 度 & 前 照 射 & $\mathrm{T} 3000 r \rightarrow$ & 反応なし & & $\begin{array}{l}6900 \\
\quad \sim 7400\end{array}$ & $\begin{array}{l}\text { 照射終了 } \\
\text { 術 }\end{array}$ & 日目に手 \\
\hline$\hat{f}$ & $61 才$ & $\begin{array}{ll}\text { 下 } & \text { 顎 } \\
\text { 再 } & \text { II }\end{array}$ & $\begin{array}{l}\text { 癌 } \\
\text { 度 }\end{array}$ & 内. 転. 浸 I 度 & ラ ジ カ ル & $\mathrm{T} 9000 \gamma \rightarrow$ B & $\begin{array}{l}\text { 反応なく } \\
\text { 連続照射 }\end{array}$ & & $\begin{array}{l}6400 \\
\sim 3900\end{array}$ & & \\
\hline 8 & 67 才 & $\begin{array}{l}\text { 上 顎 } \\
\text { 再 II }\end{array}$ & $\begin{array}{l}\text { 癌 } \\
\text { 度 }\end{array}$ & 内. 転. II 度 & ラ ジ ル ル & $\begin{array}{l}\mathrm{T} 6000 \gamma 5 \\
\text { Ras } 20 \text { 本 軽序 }\end{array}$ & $\begin{array}{l}\text { 回目頃より疲 } \\
\text { 度にみるす全 } \\
\text { 終了 }\end{array}$ & 度労 & $\begin{array}{l}6200 \\
\sim 3400\end{array}$ & $\begin{array}{l}\mathrm{T} 3000 \gamma \\
\text { 用 }\end{array}$ & 後 Ras 使 \\
\hline
\end{tabular}

備考 略字は表 II に闬じ.

外に知ることは困難である. 従来から,これが予防, 抑制 に各種薬剂が臨床応用されているが，対放療法の或をで ていない，その抑制効果も，個人差によつて成績はまち まちである。近時肝炎に対して TA の臨床応用が盛ん となり，その効果について多数の報告がみられる. TA の体内代謝に及洔す影響として最も明らかにされている ことは，焦性ブドウ酸 $\alpha$-ケトグルタール酸の酸化に対 する補酵素としての役割である。当科汸技いては，顎口 腔領域悪性腫瘍症例の放射線療法に際して, 肝庇護を目 的として，TAの踟床応用を行ない，宿醉に対しても別
表のごとき成績をえたのであるここれるつて論ずるこ とは危険であるが，報告症例が示すごとく，宿酔の発現 は，TA 未使用時に比して抑制された成績がえられた。 な拈 TA が体内に执いて活性 SH 基に移行することか らして，放射線障害としての全身反応汶して，防禦的 に作用することも考えられ，これが著しい場合は，腫瘍 細胞に対する放射線効果を抑制することる理論的に考兄 られるが, 臨床成績, 継続的組織検索結果は, TA 未使 用時となんら差異はみとらられなかつた。 


\section{結 踰}

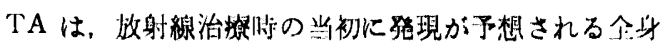
反応としての赛酔を抑制して，一定線量炤射を可能とす るために一助となりえたものと满える。

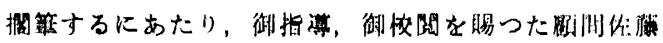
仆吉救授に梁㩆少る。

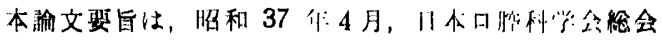
において器装した。

\section{考文 献}

1) Paterson, R. : The treatment of malignant dissase by Radium and X-Ray therapy., London (1948), Edward
Arnold Company.

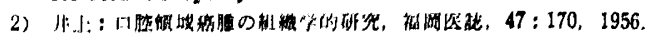

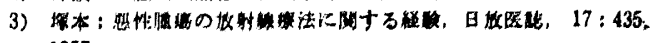
1957.

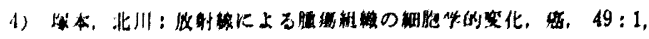
1958.

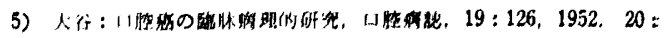
193, 1953. $21: 93,1954$.

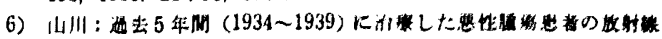

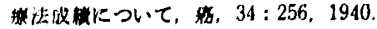

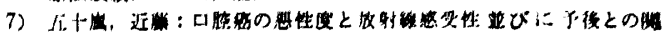

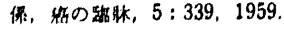

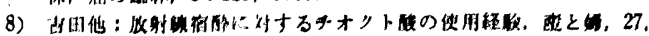
$97,1960$.

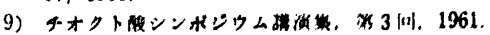

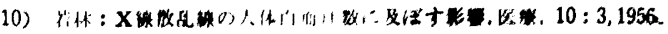

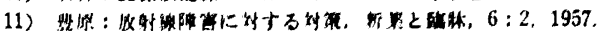

